UDC 578.825.:578.222

DOI: $10.15587 / 2519-8025.2018 .124689$

\title{
ANTIVIRAL AND APOPTOSIS MODULATING POTENTIAL OF FLUORINATED DERIVATIVES OF URACIL
}

\author{
(C) K. Naumenko, A. Golovan, L. Zelena, Yu. Shermolovych, G. Gudz, S. Zagorodnya
}

Першим вірусом класифікованим, як онкологічний був вірус Епштейна-Барр. Метою роботи було дослідити біологічні властивості фторованих похідних на основі ураџилу. Згідно прогнозування РАSS, сполуки G26 та G27 можуть мати противірусну активність. Анти-ВЕБ активність іn vitro була показана для обох досліджуваних сполук. Таким чином, похідні урацилу є перспективними для створення нових антивірусних агентів

Ключові слова: вірус Епштейна-Барр, фторовані аналоги нуклеозидів, апоптоз, in silico ma in vitro

\section{Introduction}

Epstein-Barr virus (EBV) is a member of the herpesvirus family. As with other herpesviruses, EBV is an enveloped virus that contains a DNA core surrounded by an icosahedral nucleocapsid and a tegument $[1,2]$. Although herpesviruses are ubiquitous in nature, humans serve as the only natural host for EBV. It is now known that EBV infects $>90 \%$ of the adult human population [3]. Upon infection, the individual remains a lifelong carrier of the virus [4].

Approximately 2 million cases of cancer each year are caused by infectious agents [5]. EBV was the first tumor virus identified from cultured lymphoblasts of Burkitt's lymphomas and its potential role as a causative agent of EBV-associated tumors has been the important subject of such investigation approximately for the last 40 years. EBV is classically associated with infectious mononucleosis (IM), Burkitt's lymphoma [6, 7]. The role of EBV in the pathogenesis of epithelial tumors - namely, undifferentiated nasopharyngeal and gastric carcinoma - remains unclear but is thought to result from the aberrant establishment of latent viral infection [1]. The range of EBVassociated diseases has included oral hairy leukoplakia from AIDS patients, Hodgkin's disease, T-cell lymphoma, lymphoproliferative diseases (LPD) of primary and secondary immunodeficiency and lymphoepithelioma-like carcinoma of the stomach, thymus, lung and salivary gland [8].

In the past few decades, human malignancies associated with Epstein-Barr virus (EBV), including a variety of malignant lymphomas and carcinomas, have been well documented. According to the World Health Organization (WHO) classification of lymphoid tumors, disease entities, such as endemic Burkitt lymphoma, lymphomatoid granulomatosis, reveal a high prevalence of EBV positivity [9].

\section{Literature review}

In the past decades, computational techniques like virtual screening have proven to be of greate use to make the drug development process faster and less expensive. The most commonly targeted protein in herpesviruses is the thymidine kinase; other targets like viral helicases, proteases or the protein-protein interfaces of replication proteins are also being investigated [10].

The importance of nucleoside drugs for clinical use and the clear-cut molecular mechanisms underlying their biological activities alongside the increasing concern about drug resistance encountered with antiviral and anticancer chemotherapy has led to an intensified search by bio-organic and medicinal chemists for novel nucleoside analogs as more efficacious drug candidates [11]. The use of unnatural heterocycles as nucleobases in the design of novel nucleoside analogs not only enhances in vivo stability but also confers novel biologically interesting activities [12]. Analogs of nucleoside have been playing a major role in treating tumor and virus either as selective inhibitors of certain obligatory enzymes for cancer or viral replication or as nucleic acid chain terminators which interrupt the replication of cancer cells or a virus. They are chemically modified analogs of natural nucleosides, nucleotides, and bases, which are endogenous metabolites involved in many essential cellular processes, such as DNA and RNA synthesis, and purinergic signaling [13]. The selective introduction of a fluoro group into biologically active molecules has received much attention by medicinal chemists. Fluorinated nucleosides exhibit a wide variety of biological activity and have been used extensively as anti-tumor and antiviral agents [14]. In many cases, the stability of the nucleoside analog, particularly the stability of the glycosyl bond, is an important factor determining the biological activity as well as the therapeutic usefulness of nucleosides as a drug candidate. Fluorine substitution also has a favorable effect of increasing the metabolic stability. These findings suggest the importance of a fluorine moiety in the nucleoside as therapeutic agents. Thymidylate synthase, ribonucleotide diphosphate reductase (RDPR) and viral polymerases are the major targets by fluoronucleosides and fluoroheterocyclic bases [15].

\section{Aim and objectives of the study}

Aim - Analyze the potential antiviral and apoptosis modulating activity of fluorinated derivatives of uracil by using in silico and in vitro methods.

To achieve this aim, it was necessary to solve the following problems:

1. Identify potential biological activity and possible targets of fluorinated derivatives of uracil by using the PASS software and PharmMapper online tools.

2. Study potential antiviral and apoptosis modulating the activity of the new compounds using in vitro methods. 


\section{Material and methods}

Cell culture. Raji is a human Burkitt's lymphoma-derived cell line, harboring the latent form of EBV cycle. B95-8 is a lymphoblastoid cell line, EBVtransformed and chronically producing viruses. Raji, B95-8 cell lines obtained from the Bank of Cell Cultures of the Institute of Virology of the Russian Academy of Medical Sciences. All cell lines were grown in $90 \%$ of RPMI 1640 ("Sigma”, USA) supplemented with $10 \%$ fetal bovine serum (FBS, "Sigma", USA), 2 mM Lglutamine and gentamicin $(100 \mu \mathrm{g} / \mathrm{ml})$ ("Sigma", USA) in tissue culture flasks. Cultivation was performed at 37 ${ }^{\circ} \mathrm{C}$ in a $5 \% \mathrm{CO}_{2}$ atmosphere.

Chemical substances. Derivates of fluorinated analogs of 5-(p-tolilsulfonil)-6(polyfluoroalkyl)uracil (compounds G26 and G27) were synthesized at the Institute of Organic Chemistry of the National Academy of Sciences of Ukraine. As reference drug was used ganciclovir (Cymeven, Roche, Switzerland).The substances dissolved in DMSO and filtered through a filter with a pore diameter of 0.22 microns (Sarstedt, USA). Working solutions were prepared to the culture medium.

Neutral Red Uptake assay (NRU). The NRU method was used as previously described [16]. After the neutral red had dissolved, the absorbance of the plate was determined spectrophotometrically at $538 \mathrm{~nm}$ on a Multiskan FC universal microplate reader (Thermo Scientific, USA).

Trypan Blue Exclusion Test of Cell Viability. The dye exclusion test is used to determine the number of viable cells present in a cell suspension. It is based on the principle that live cells possess intact cell membranes that exclude trypan blue, whereas dead cells do not. In this test, a cell suspension is simply mixed with dye and then visually examined to determine whether cells take up or exclude dye. The trypan blue exclusion test was used as previously described [17].

MTT assay. The MTT staining method as described by Mosmann was used with minor modifications [16]. The absorbance was determined at $538 \mathrm{~nm}$ on a Multiskan FC universal microplate reader (Thermo Scientific, USA).

Real-time PCR detection of viral DNA. A realtime PCR, the assay was performed to assess the antiviral activity of various drugs against EBV [18]. For detection of antiviral activity of studied compounds, Raji cells were infected with EBV 0,3 ml/cell. DNA isolation of virus from samples conducted using «innuPREP Virus DNA Kit» («Analityk Jena AC», Germany). DNA concentration was measured by Biophotometer («Eppendorf», Germany). To detect DNA EBV was using a set «Amplisens ${ }^{\circledR E B V}-\mathrm{FL} » \quad$ («Amplisens», Russian) according to manufacturer's recommendations for detection in real time (qTOWER 2.2., Germany).

Analysis apoptosis by flow cytometry. Flow cytometry was performed to quantitatively detect the apoptotic cells processed by a hypotonic solution of propidium iodide (50 $\mu \mathrm{g} / \mathrm{ml}$, Sigma США) [19]. The sub-G1 peak was measured with a flow cytometer Beckman Coulter Epics XL (USA) and analyzed using Flowing Software, version 2,5 (USA).
Evaluation of nuclear condensation by Hoechst 33342 staining. Cells were seeded at a concentration of $5 \times 10^{5}$ cells $/ \mathrm{ml}$ in a 24 -well plate and treated with different concentrations of compounds. After incubation, the cells were collected by centrifugation and suspended in $1 \mathrm{ml}$ of phosphate buffer solution (PBS, pH-7.4). PBS was then removed by centrifugation, and the cells were incubated for $30 \mathrm{~min}$ at $37^{\circ} \mathrm{C}$ with $100 \mu \mathrm{l}$ of the DNAspecific dye Hoechst $33342(0.05 \mathrm{mg} / \mathrm{ml})$. After incubation, the cells were suspended in $1 \mathrm{ml}$ of PBS. PBS was then removed by centrifugation. Cells were suspended in $50 \%$ glycerin ("Sigma", USA) with $4 \%$ paraformaldehyde ("Sigma", USA). Morphological changes were observed under Ulab LW300TF fluorescent microscope x100 (USA).

PASS prediction. PASS (Prediction of Activity Spectra for Substances) is a computer-based program used for the prediction of different types of biological activity for different substances. Prediction of this spectrum by PASS based on structural activity relationship analysis of the training set containing more than 250000 compounds exhibiting more than 3750 kinds of biological activities. PASS works on the basis of structural activity relationship (SAR) analysis. The proposed web server is freely available at http://www.pharmaexpert.ru/ passonline/ [20].

PharmMapper. The PharmMapper online tool is a web server for potential drug target identification by reversed pharmacophore matching the query compound against an in-house pharmacophore model database. The PharmMapper web server is freely available at http://lilab.ecust.edu.cn/pharmmapper/ [21].

Statistical analysis. Statistical analysis was performed according to standard approaches (parametric criteria) using the computer program Microsoft Excel 2010 [22]. Data are presented as means \pm standard deviation (SD). All studies were conducted in three replies. The difference between the mean values was estimated according to the t-criterion and was considered to be valid at $\mathrm{p}<0.05$. The selective index (SI), a marker of antiviral activity, was determined as the ratio of $\mathrm{CC}_{50}$ to $\mathrm{EC}_{50}$.

\section{Result and discussion}

With the view of finding the specific activity of these compounds, they were exploited for prediction of activity, using PASS. The predicted activity spectrum of a compound is estimated as $\mathrm{Pa}$ (probably activity) and $\mathrm{Pi}$ (probable inactivity). Accordingly, the activities of compounds taken into consideration for the possibility of particular pharmacological activity are the ones showing more $\mathrm{Pa}$ value than $\mathrm{Pi}$. Two compounds exhibited a number of biological activities as in Table 1 .

In the present study, PASS predicted that the antiviral (poxvirus, picornavirus, herpesvirus), nucleotide metabolism regulator, DNA polymerase I inhibitor, antineoplastic (non-Hodgkin's lymphoma), CDK9/cyclin T1 inhibitor activity were expressed by compound G26. The TP53 expression enhancer, DNA polymerase I inhibitor, thymidylate 5'-phosphatase inhibitor, antiviral (poxvirus, herpesvirus), antineoplastic (non-Hodgkin's lymphoma, carcinoma), RNA directed DNA polymerase inhibitor was expressed by compound G27. 
Table 1

Predicted biological activity for compounds using PASS

\begin{tabular}{|c|c|c|c|}
\hline Compound & \multirow{2}{*}{$\begin{array}{r}\mathrm{Pa} \\
0,649\end{array}$} & \multirow{2}{*}{$\begin{array}{r}\mathrm{Pi} \\
0,012\end{array}$} & Possible activity \\
\hline G26 & & & Antiviral (Poxvirus) \\
\hline & 0,599 & 0,019 & Nucleotide metabolism regulator \\
\hline & 0,550 & 0,032 & Antiviral (Picornavirus) \\
\hline & 0,495 & 0,011 & Antineoplastic antimetabolite \\
\hline & 0,478 & 0,010 & DNA polymerase I inhibitor \\
\hline & 0,464 & 0,055 & Antineoplastic (non-Hodgkin's lymphoma) \\
\hline \multirow[t]{2}{*}{$\mathrm{OH}$} & 0,445 & 0,019 & Antiviral (Herpes) \\
\hline & 0,394 & 0,107 & Antineoplastic \\
\hline \multirow[t]{9}{*}{ G27 } & 0,758 & 0,016 & TP53 expression enhancer \\
\hline & 0,458 & 0,013 & Antineoplastic antimetabolite \\
\hline & 0,449 & 0,013 & DNA polymerase I inhibitor \\
\hline & 0,448 & 0,036 & Thymidylate 5'-phosphatase inhibitor \\
\hline & 0,425 & 0,026 & Antiviral (Poxvirus) \\
\hline & 0,412 & 0,097 & Antineoplastic (non-Hodgkin's lymphoma) \\
\hline & 0,400 & 0,018 & RNA directed DNA polymerase inhibitor \\
\hline & 0,397 & 0,047 & CDK9/cyclin T1 inhibitor \\
\hline & 0,372 & 0,049 & Antiviral (Herpes) \\
\hline
\end{tabular}

In silico methods allows for screening of a large number of compounds. Any predicted property must be confirmed or disproved in the biological model. Accordingly, in vitro analysis of these compounds was carried out. The cytotoxic effect of compound G26 and G27 were analyzed by trypan blue; MTT and NRU assay (Fig. 1). Samples for analysis were taken after $48 \mathrm{~h}$ incubation with a treatment of studied compounds.

The cytotoxicity test of two compounds showed $\mathrm{CC}_{50}$ value ranged from $206 \mu \mathrm{g} / \mathrm{ml}$ to $1316 \mu \mathrm{g} / \mathrm{ml}$ (Table 2). These compounds G26 and G27 are considered to be non-cytotoxic at Raji cell line, as the value ranged from $502 \mu \mathrm{g} / \mathrm{ml}$ to $1316 \mu \mathrm{g} / \mathrm{ml}$. Compound G26 is considered to be more cytotoxic at B95-8 cell line, as the value ranged from $206 \mu \mathrm{g} / \mathrm{ml}$. B95-8 is Blymphocyte cell culture, which transformed by EBV and chronically producing viruses. Thus, a higher level of cytotoxic of studied compounds may be explained by producing viruses and the effect of the compounds on the reproduction of viruses in cells.

Thus, compounds are an important value for use in the antiviral study due to their low toxic effect. Thus, mechanism of action may be considered at blocking replication of EBV. Results from antiviral screening showed that both fluorinated analogs of the uracil exert good activity, as shown in Table 3. In particular, compound G26 and G27 showed a high level of antiviral activity for Raji and B95-8 cell line.

According to PASS prediction, it may block the synthesis of DNA as an inhibitor of the polymerase. Also, this compounds may play an important role in blocking enzymes necessary for transcription and replication of virus DNA, such as CDK9/cyclin T1 and thymidylate 5'-phosphatase. Moreover, SI is used to estimate the therapeutic effect of a drug and to identify drug candidates for further studies. In this study, both compounds could be considered as promising new antiEBV drug candidates for lytic infection of EBV.

To further understand the mechanism of action of the synthesized compounds, molecular modeling and docking studies of G26 and G27 were performed using web-server PhrmMapper (Table 4).

It is well known that analog nucleosides exert its antiviral activity by binding to DNA and blocking their synthesis. But it's important to find out what target use this compounds. Because for more and more viruses become resistant to analog nucleosides. PharmMapper is a web server for potential drug target identification based on the use of a pharmacophore mapping approach. PharmMapper server works by 'probing' the ligand into a database of pharmacophore models of binding sites. It functions on the ligand-protein reverse docking strategy and reports a potential target on the basis of the normalized fit score. It was established, that majority of the targets are enzymes that participate in the synthesis of nucleic acids and apoptotic proteins. It was shown that compound G27 could be an inhibitor of the synthesis of nucleic acids by interacting with DNA topoisomerase 2, DNA primase/helicase and other. Compound G26 could inhibit the synthesis of DNA or RNA by interacting with thymidylate synthase and DNA mismatch repair protein mutL.

Also, the list of targets presents proteins, included at apoptotic cascade (Table 4, Fig. 2). It is important, because EBV is associated with cancer, so induction of apoptosis might be one of the ways of treatment of disorders. 

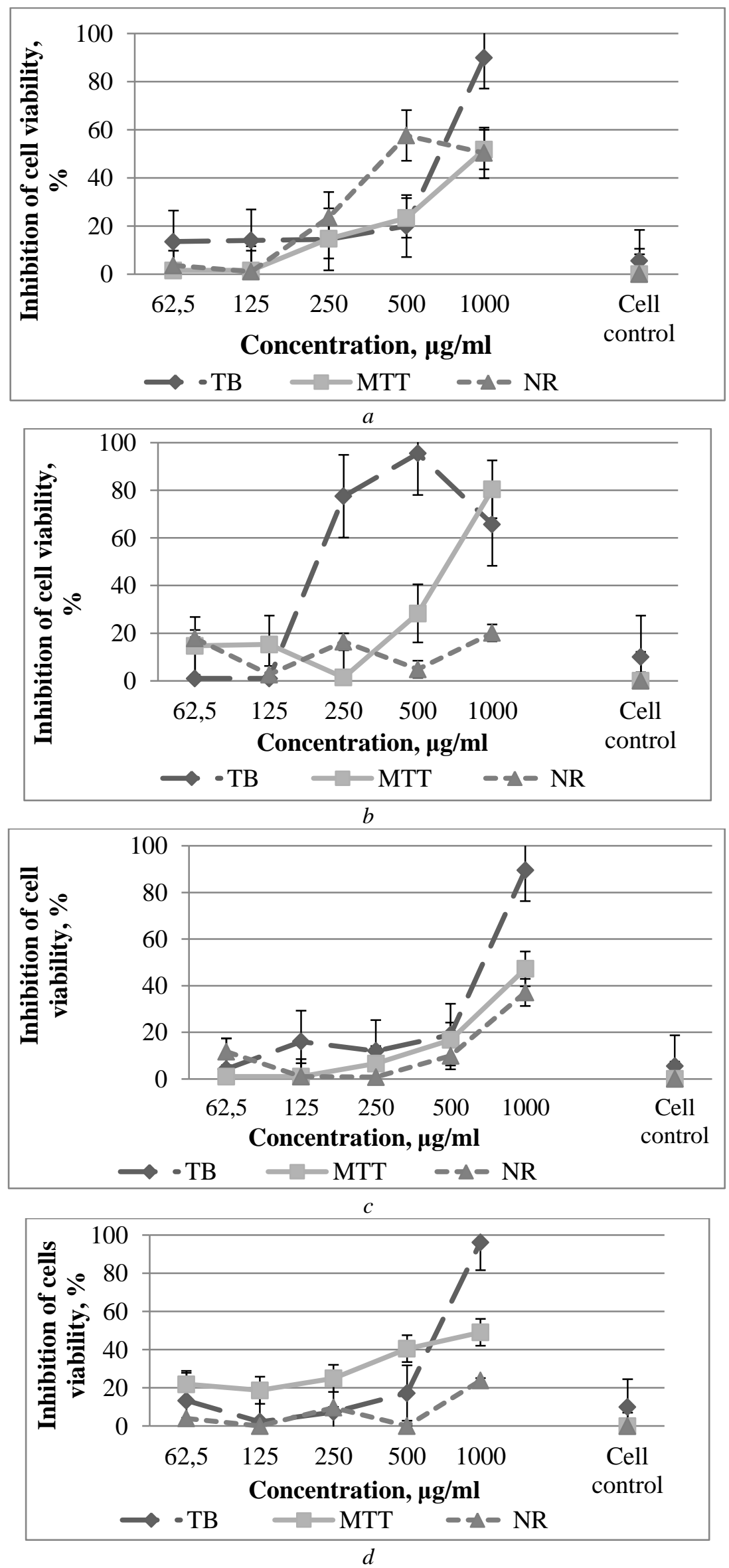

Fig. 1. The cytotoxicity of fluorinated analogs of uracil on model lymphoblastoid cell line: $a$ - the cytotoxic effect of compound G26 on Raji cells; $b$ - the level of cytotoxicity of compound G26 on B95-8 cell line; $c$ - the cytotoxic effect of compound G27 on Raji cells; $d$ - the level of cytotoxicity of compound G27 on B95-8 cell line, p<0.05 in comparison with untreated cells in all cases 
Table 2

The cytotoxicity of the studied compounds on the $\mathrm{CC}_{50}$ index $(\mu \mathrm{g} / \mathrm{ml})$

\begin{tabular}{|c|c|c|c|c|c|c|}
\hline \multirow{2}{*}{$\begin{array}{c}\text { Substa- } \\
\text { nces }\end{array}$} & \multicolumn{5}{|c|}{ Raji } & \multicolumn{4}{c|}{ B95-8 } \\
\cline { 2 - 7 } & \multicolumn{5}{|c|}{ Methods } & Neutral red assay \\
\hline & Trypan blue & MTT assay & Neutral red assay & Trypan blue & MTT assay & 1081 \\
\hline G26 & 1250 & 952 & 544 & 262 & 317 & 1192 \\
\hline G27 & 1316 & 1038 & 952 & 520 & 206 & 1042 \\
\hline GCV & 962 & 560 & 502 & 833 & 1020 & \\
\hline
\end{tabular}

Antiviral activity fluorinated derivatives of uracil on $\mathrm{EBV}$ and $\mathrm{EC}_{50}$

Table 3

\begin{tabular}{|c|c|c|c|c|c|c|}
\hline \multirow[b]{2}{*}{ Compounds } & \multirow[b]{2}{*}{$\mathrm{CC}_{50}{ }^{\mathrm{a}}$} & \multicolumn{2}{|c|}{ Raji } & \multirow[b]{2}{*}{$\mathrm{CC}_{50}$} & \multicolumn{2}{|c|}{ B95-8 } \\
\hline & & $\begin{array}{c}\text { Antiviral } \\
\text { activity }\left(\mathrm{EC}_{50}{ }^{\mathrm{b}}\right)\end{array}$ & $\begin{array}{l}\text { Selectivity } \\
\text { index }\left(\mathrm{SI}^{\mathrm{c}}\right)\end{array}$ & & $\begin{array}{c}\text { Antiviral } \\
\text { activity }\left(\mathrm{EC}_{50}\right)\end{array}$ & $\begin{array}{l}\text { Selectivity } \\
\text { index (SI) }\end{array}$ \\
\hline G26 & 952 & 50 & 19 & 317 & 75 & 4 \\
\hline G27 & 1038 & 100 & 10 & 206 & 65 & 3 \\
\hline GCV & 560 & 5 & 112 & 1020 & 10 & 102 \\
\hline
\end{tabular}

Note: ${ }^{a}$ - The $50 \%$ cytotoxic concentration for Raji and B95-8 cell in $\mu \mathrm{g} / \mathrm{ml} ;{ }^{b}$ - Concentration of compound ( $\left.\mu \mathrm{g} / \mathrm{ml}\right) \mathrm{producing} 50 \%$ inhibition of $E B V$ reproduction; ${ }^{c}$ - Selectivity index $(S I)=C C_{50} E C$

Table 4

Potential targets of fluorinated compounds predicted by PharmMapper

\begin{tabular}{|c|c|c|c|}
\hline \multicolumn{2}{|c|}{ Compound G26 } & \multicolumn{2}{c|}{ Compound G27 } \\
\hline Target name & Fit score & Target name & Fit score \\
\hline Thymidylate synthase & 5.351 & DNA topoisomerase 2 & 3.837 \\
\hline DNA mismatch repair protein mutL & 4.372 & Mitogen-activated protein kinase 14 & 3.827 \\
\hline Gag-Pol protein & 4.304 & DNA primase/helicase & 3.789 \\
\hline Serine/threonineprotein kinase & 4.2 & Tyrosine-protein kinase & 3.722 \\
\hline Neuraminidase & 4.2 & Gag-Pol polyprotein & 3.711 \\
\hline DNA topoisomerase 6 sub. B & 4.086 & Deoxyribonucleotidase, mitochon- & 3.696 \\
\hline drial & Thymidine kinase & 3.662 \\
\hline Nucleoside diphosphate kinase, cytosolic & 4.078 & Apoptotic protease-activating factor & 3.656 \\
\hline
\end{tabular}

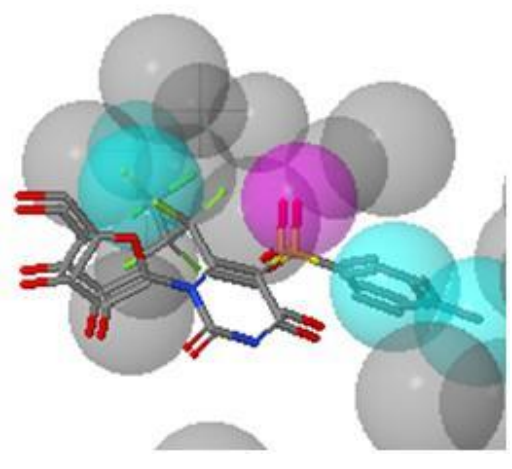

$a$
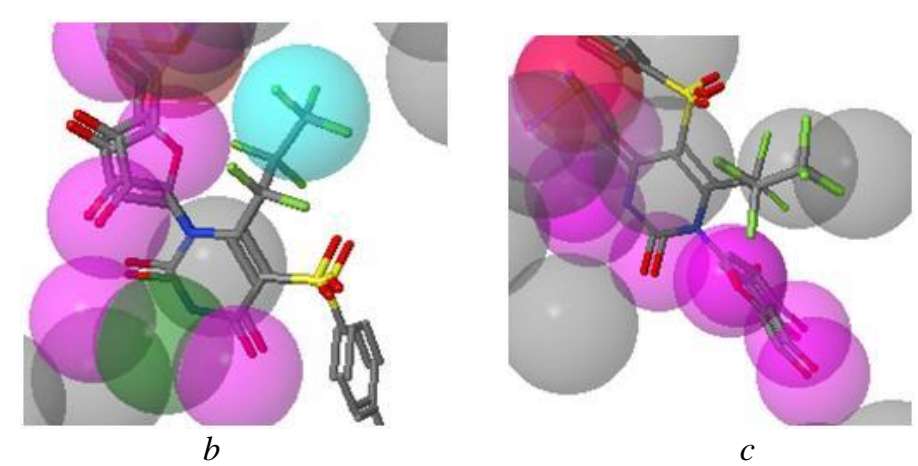

$c$

Fig. 2. The pharmacophore models of three targets for compound G27: $a$-Mitogen-activated protein kinase 14; $b-5$ (3)-deoxyribose nucleotidase, mitochondrial; $c$ - Apoptotic protease-activating factor 1

EBV persists for life in low number metabolically quiescent memory-B-cells as a methylated and transcriptionally silenced nuclear dsDNA episome, expressing only non-coding small RNAs and several latent proteins and being invisible to immune responses. Also, EBV has been thought to counter apoptosis during latency indirectly through LMP1-mediated activation of NF-Bregulated genes. The Bcl-2 homologs encoded by the EBV BHRF1 and BALF1 ORFs are expressed only during the viral lytic cycle, presumably to prevent premature cell death during active EBV replication [23]. New strategies are emerging for the virus-targeted therapy to treat EBV-associated malignancies, generally consisting of two components. The first step is aimed at initiating virus reactivation and triggering recognition of the tumor cells by the immune system. The second step is the administration of an antiviral drug which can be metabolized exclusively in cells expressing viral lytic cycle proteins [24]. Another way it is the elimination of tumor cells by apoptosis-inducing by different chemical or nature compounds. For studies of induction of apoptosis by derivatives of uracil, flow cytometry and fluorescence microscopy were used (staining by Hoechst 33342) (Fig. 3). 

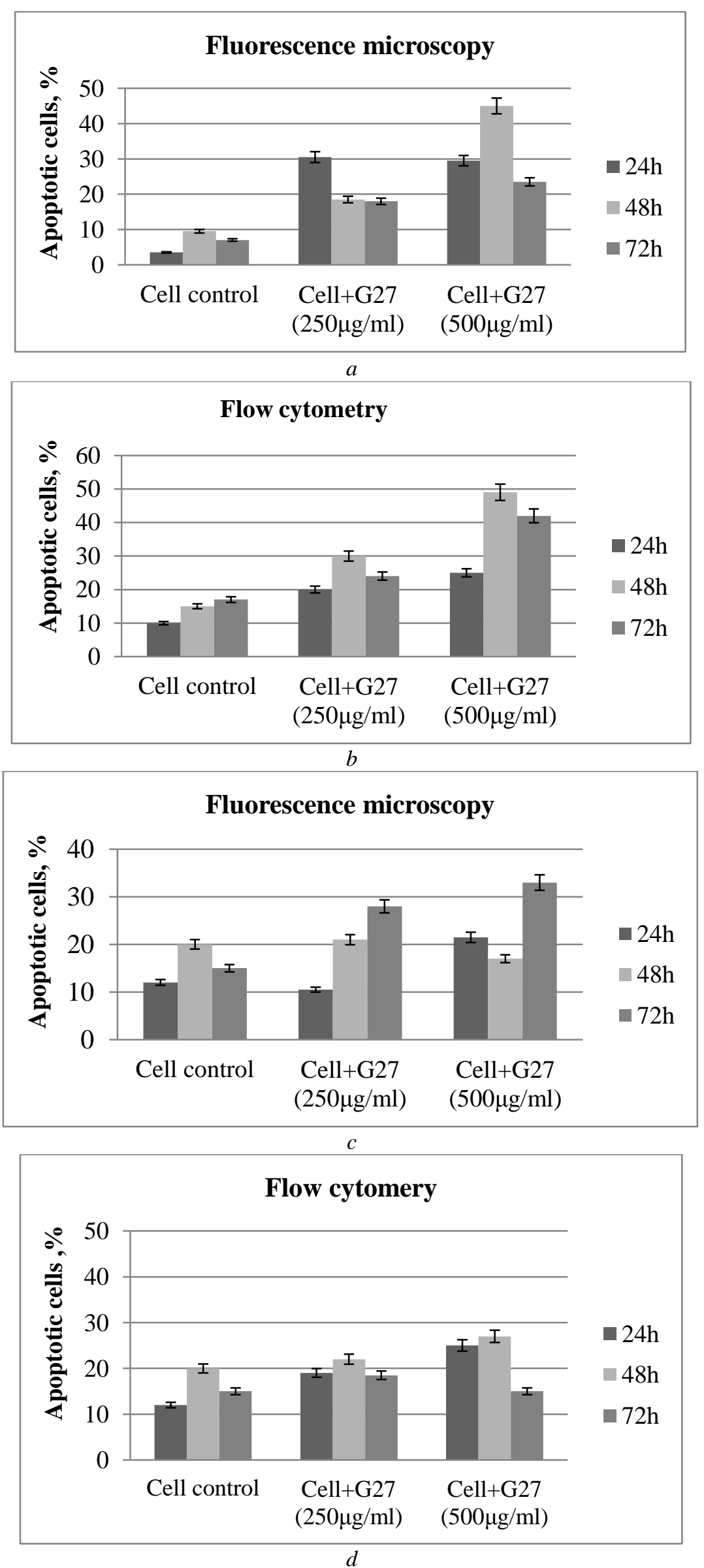

Fig. 3. Detection of apoptotic cell in lymphoblastoid cell line treated with compound G27: $a$ - the apoptosis modulation effect on Raji cells; $b$ - the percentage of apoptosis cells on B95-8 cell line; $c$ - the apoptosis modulation effect on Raji cells; $d$ - the percentage of apoptosis cells on B95-8 cell line, $\mathrm{p}<0.05$ in comparison with untreated cells in all cases 
The action of compound G27 has been studied at $500 \mu \mathrm{g} / \mathrm{ml}$ and $250 \mu \mathrm{g} / \mathrm{ml}$ concentrations for 24,48 and $72 \mathrm{~h}$. In both concentrations of 500 and $250 \mu \mathrm{g} / \mathrm{ml}$ the compound induced apoptosis of the non-infected transformed Raji and B95-8 cells. It was a significant increase in the percentage of apoptotic cells by 48 hours for Raji at $500 \mu \mathrm{g} / \mathrm{ml}$ concentration. It was established that the percentage of apoptotic cells exceeds control values and was $49 \%$, and it was $40 \%$ after $72 \mathrm{~h}$. It was showed less percentage of the apoptotic cell on B95-8 cell line. This effect may be due to the ability of the virus to block the various stages of the apoptotic cascade.

Induction of apoptosis might be caused by different targets, included in apoptosis cascades, such as apoptotic protease-activating factor or MAP kinase. So it can be assumed that the test compound possesses the antiviral activity against both forms of EBV infection and the destruction of cells infected with virus occurs through apoptosis.

EBV is gammaherpesvirus that is ubiquitous in humans, infecting more than $90 \%$ of the world population $[4,8]$. To date, there are no available drugs to target latent EBV, and the existing broad-spectrum antiviral drugs are mainly active against lytic viral infection. Thus, using computational molecular docking and in vitro methods, a new class of fluorinated nucleoside analogs of uracil was studied. Fluorinated nucleosides exhibit a wide variety of biological activity and have been used extensively as anti-tumor and antiviral agents. Viral polymerase is one of the most common and established targets of nucleoside and the presence of fluoro group makes it unique in terms of their chemical, biological and structural properties [15]. Our research showed that new derivatives of uracil with fluoro group have antiviral activity and might be affected at other enzymes of replication, such as DNA topoisomerase 2, DNA primase/helicase. Also, it was established that fluorinated derivatives of uracil (compound G26 and G27) could induce apoptosis in EBV-transformed cell line Raji and B95-8. According to the literary data, nucleoside analogs mimic natural nucleosides in term of uptake and metabolism [15, 24]. Further, they can incorporate into newly synthesized DNA resulting in chain termination. Some of these drugs also inhibit key enzymes involved in the biosynthesis of purine and pyrimidine nucleotides and RNA synthesis as well as directly activate the apoptosis as an anti-cancer agent [15]. Also according to the prediction of targets these compounds may interact with different apoptotic proteins such as apoptotic protease-activating factor, MAP kinase, deoxyribonucleotidase (mitochondrial) and some classes of protein kinase.

\section{Conclusion}

1. This study indicates that the in silico virtual screening of different compounds may be of added value in the identification of new antiviral molecules. According to PASS prediction, all studied compounds might have antiviral and antineoplastic activity. There were also identified several classes of different proteins, which play an important role in the cell cycle and might be a potential target for the action of studied derivatives.

2. In vitro studies of fluorinated uracil derivatives showed their high antiviral activity against EBV in Raji cell culture (an acute form of infection). Selectivity indices were 19 (compound G26) and 10 (compound G27). It was established that only compound G27 had induced apoptosis at cell line Raji and B95-8 (B-lymphomas). Thus, the results of this study openf new directions in the study of this class compounds.

\section{References}

1. Epstein-Barr virus: more than 50 years old and still providing surprises / Young L. S., Yap L. F., Murray P. G. // Nature Reviews Cancer. 2016. Vol. 16, Issue 12. P. 789-802. doi: 10.1038/nrc.2016.92

2. A possible link between the Epstein-Barr virus infection and autoimmune thyroid disorders / Dittfeld A., Gwizdek K., Michalski M., Wojnicz R. // Central European Journal of Immunology. 2016. Vol. 3. P. 297-301. doi: 10.5114/ceji.2016.63130

3. The biological properties of different Epstein-Barr virus strains explain their association with various types of cancers $/$

Tsai M.-H., Lin X., Shumilov A., Bernhardt K., Feederle R., Poirey R. et. al. // Oncotarget. 2016. Vol. 8, Issue 6. doi: 10.18632/oncotarget.14380

4. Thompson M. P. Epstein-Barr Virus and Cancer // Clinical Cancer Research. 2004. Vol. 10, Issue 3. P. 803-821. doi: 10.1158/1078-0432.ccr-0670-3

5. Global burden of cancers attributable to infections in 2008: a review and synthetic analysis / De Martel C., Ferlay J., Franceschi S., Vignat J., Bray F., Forman D., Plummer M. // The Lancet Oncology. 2012. Vol. 13, Issue 6. P. 607-615. doi: 10.1016/s1470-2045(12)70137-7

6. Hutt-Fletcher L. M. The Long and Complicated Relationship between Epstein-Barr Virus and Epithelial Cells // Journal of Virology. 2016. Vol. 91, Issue 1. P. e01677-16. doi: 10.1128/jvi.01677-16

7. De Clercq E., Li G. Approved Antiviral Drugs over the Past 50 Years // Clinical Microbiology Reviews. 2016. Vol. 29, Issue 3. P. 695-747. doi: $10.1128 / \mathrm{cmr} .00102-15$

8. Hayashi K., Teramoto N., Akagi T. The animal in vivo models of EBV-associated lymphoproliferative diseases: special references to rabbit models // Histology, and Histopathology. 2002. Vol. 17, Issue 04. P. 1293-1310.

9. Senile Epstein-Barr Virus-Associated B-Cell Lymphoproliferative Disorders: a Mini Review / Shimoyama Y., Oyama T., Asano N., Oshiro A., Suzuki R., Kagami Y. et. al. // Journal of Clinical and Experimental Hematopathology. 2006. Vol. 46, Issue 1. P. 1-4. doi: 10.3960/jslrt.46.1

10. In silico virtual screening approaches for anti-viral drug discovery / Murgueitio M. S., Bermudez M., Mortier J., Wolber G. // Drug Discovery Today: Technologies. 2012. Vol. 9, Issue 3. P. e219-e225. doi: 10.1016/j.ddtec.2012.07.009

11. Fluorinated nucleosides as an important class of anticancer and antiviral agents / Cavaliere A., Probst K. C., Westwell A. D., Slusarczyk M. // Future Medicinal Chemistry. 2017. Vol. 9, Issue 15. P. 1809-1833. doi: 10.4155/fmc-2017-0095

12. Xia Y., Qu F., Peng L. Triazole Nucleoside Derivatives Bearing Aryl Functionalities on the Nucleobases Show Antiviral and Anticancer Activity // Mini-Reviews in Medicinal Chemistry. 2010. Vol. 10, Issue 9. P. 806-821. doi: $10.2174 / 138955710791608316$ 
13. Metabolism, Biochemical Actions, and Chemical Synthesis of Anticancer Nucleosides, Nucleotides, and Base Analogs / Shelton J., Lu X., Hollenbaugh J. A., Cho J. H., Amblard F., Schinazi R. F. // Chemical Reviews. 2016. Vol. 116, Issue 23. P. 14379-14455. doi: 10.1021/acs.chemrev.6b00209

14. Synthesis and Duplex-Stabilizing Properties of FluorinatedN-Methanocarbathymidine Analogues Locked in the C3'endoConformation / Jung M. E., Dwight T. A., Vigant F., Østergaard M. E., Swayze E. E., Seth P. P. // Angewandte Chemie. 2014. Vol. 126, Issue 37. P. 10051-10055. doi: 10.1002/ange.201405283

15. Liu P., Sharon A., Chu C. K. Fluorinated nucleosides: Synthesis and biological implication // Journal of Fluorine Chemistry. 2008. Vol. 129, Issue 9. P. 743-766. doi: 10.1016/j.jfluchem.2008.06.007

16. Van Tonder A., Joubert A. M., Cromarty A. Limitations of the 3-(4,5-dimethylthiazol-2-yl)-2,5-diphenyl-2H-tetrazolium bromide (MTT) assay when compared to three commonly used cell enumeration assays // BMC Research Notes. 2015 . Vol. 8, Issue 1. P. 47. doi: 10.1186/s13104-015-1000-8

17. Strober W. Trypan Blue Exclusion Test of Cell Viability // Current Protocols in Immunology. 2001. doi: 10.1002/ 0471142735.ima03bs21

18. A method for evaluating antiviral drug susceptibility to Epstein-Barr virus / Romain C. A., Balfour H. H., Vezina H. E., Holman C. J. // Virus Adaptation and Treatment. 2010. Vol. 2. P. 1-7. doi: 10.2147/vaat.s8575

19. Riccardi C., Nicoletti I. Analysis of apoptosis by propidium iodide staining and flow cytometry // Nature Protocols. 2006. Vol. 1, Issue 3. P. 1458-1461. doi: 10.1038/nprot.2006.238

20. Investigation of Phytocompounds and Computational Approach for the Evaluation of Therapeutic Properties of Ethanolic Leaf Extract of Callistemon citrinus / Balasundaram A., Ragupathy R., Sankar Sh., Thiyagarajan M., Ravi L., Karuppasamy R., Veerappapillai Sh. // Int. J. Pharm. Sci. Rev. Res. 2016. Vol. 37, Issue 01. P. 110-116.

21. PharmMapper 2017 update: a web server for potential drug target identification with a comprehensive target pharmacophore database / Wang X., Shen Y., Wang S., Li S., Zhang W., Liu X. et. al. // Nucleic Acids Research. 2017. Vol. 45, Issue W1. P. W356-W360. doi: 10.1093/nar/gkx374

22. Lapach S. N., Chubenco A. V., Babich P. N. Statistical methods in medical and biological research using Excel. Moscow, 2002. $407 \mathrm{p}$.

23. Epstein-Barr virus EBNA2 blocks Nur77- mediated apoptosis / Lee J. M., Lee K.-H., Weidner M., Osborne B. A., Hayward S. D. // Proceedings of the National Academy of Sciences. 2002. Vol. 9, Issue 18. P. 11878-11883. doi: 10.1073/ pnas. 182552499

24. NovaliA Z., van Rossen T. M. Agents and Approaches for Lytic Induction Therapy of Epstein-Barr Virus Associated Malignancies // Medicinal chemistry. 2016. Vol. 6, Issue 7. doi: 10.4172/2161-0444.1000384

Дата надходження рукопису 16.01.2018

Krystyna Naumenko, Junior Researcher, Department of Reproduction of Viruses, D. K. Zabolotny Institute of Microbiology and Virology of National Academy of Sciences of Ukraine, Akademika Zabolotnoho str., 154, Kyiv, Ukraine, 03143

E-mail: krystyn.naumenko@gmail.com

Anna Golovan, PhD, Junior Researcher, Department of Reproduction of Viruses, D. K. Zabolotny Institute of Microbiology and Virology of National Academy of Sciences of Ukraine. Akademika Zabolotnoho str., 154, Kyiv, Ukraine, 03143

E-mail: golovan26@ukr.net

Lubov Zelena, PhD, Senior Researcher, Department of Physiology of Industrial Microorganisms, D. K. Zabolotny Institute of Microbiology and Virology of National Academy of Sciences of Ukraine, Akademika Zabolotnoho str., 154, Kyiv, Ukraine, 03143

E-mail: zelenalyubov@gmail.com

Yuriy Shermolovich, Doctor of Chemical Sciences, Professor, Head of Department, Department of Chemistry of Organic Sulfur Compounds, Institute of organic chemistry of National Academy of Sciences of Ukraine. Murmanska str., 5, Kyiv, Ukraine, 02660

E-mail: sherm@ioch.kiev.ua

Gudz Ganna, PhD, Senior Researcher, Department of Chemistry of Organic Sulfur Compounds, Institute of organic chemistry of National Academy of Sciences of Ukraine, Murmanska str., 5, Kyiv, Ukraine, 02660 E-mail: anutagudz@gmail.com

Svitlana Zagorodnya, PhD, Head of Department, Department of Reproduction of Viruses, D. K. Zabolotny Institute of Microbiology and Virology of National Academy of Sciences of Ukraine

Akademika Zabolotnoho str., 154, Kyiv, Ukraine, 03143

E-mail: svetazagorodnya@ukr.net 